\title{
UJI KUALITAS HAND SANITIZER EKSTRAK DAUN KUNYIT (Curcuma longa Linn)
}

\author{
NING BAIZUROH $^{1}$, YAHDI $^{1}$, DAN YULI KUSUMA DEWI ${ }^{1 *}$ \\ ${ }^{1}$ Program Studi Tadris Kimia, Fakultas Tarbiyah dan Keguruan, UIN Mataram, \\ Jalan Gajah Mada No.100 Jempong, Mataram
}

*alamat email korespondensi: yulichemist@uinmataram.ac.id

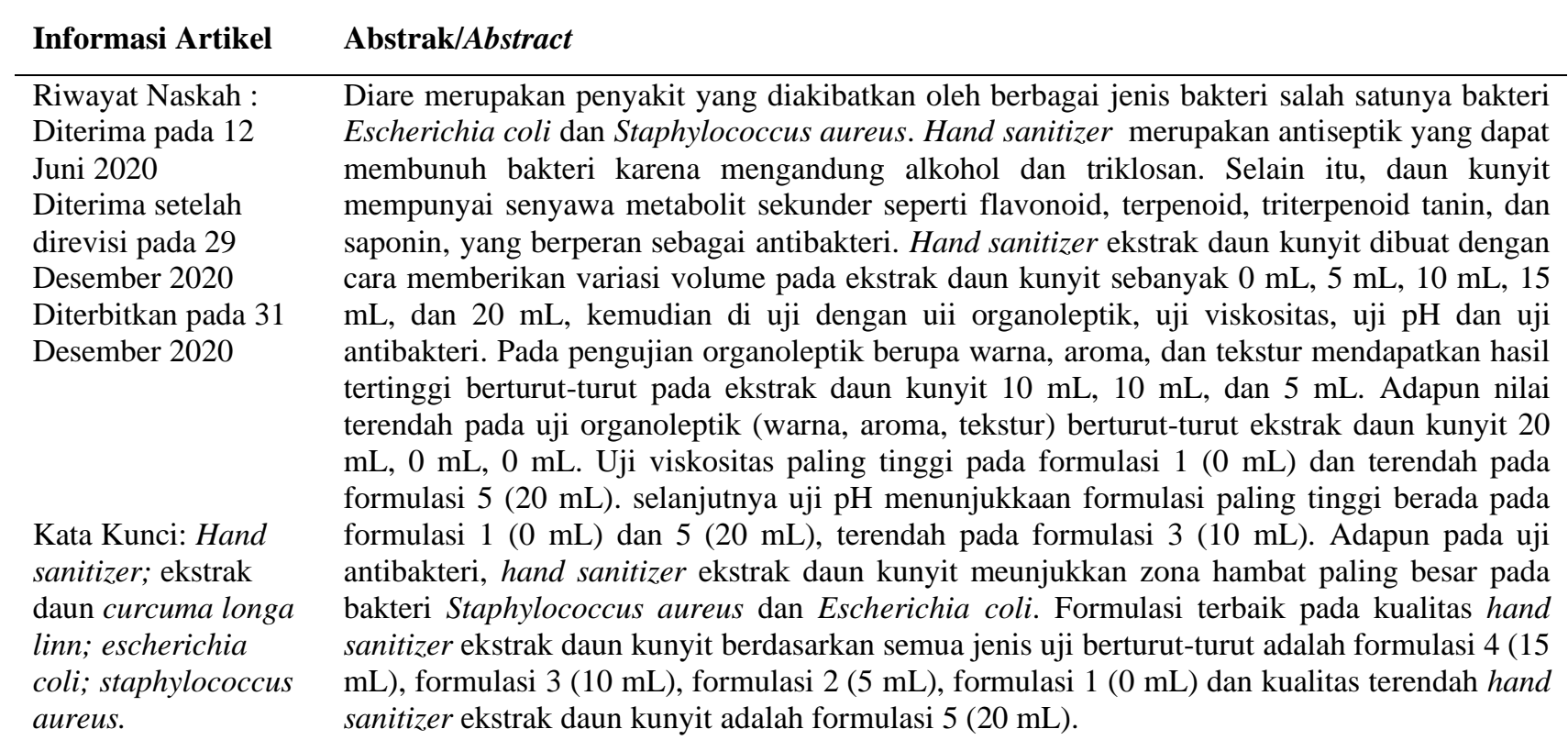

Keywords: Hand sanitizer; leaves extract curcuma longa linn; escherichia coli; staphylococcus aureus.

\begin{abstract}
Diarrhea is a disease caused by various types of bacteria such as bacteria Escherichia coli and staphylococcus aureus. Hand sanitizer is an antiseptic that can kill bacteria because it contains alcohol and triclosan. Besides, the leaves of turmeric have secondary metabolites such as flavonoids, saponins, tannins, terpenoids, and triterpenoids which act as antibacterial. Hand sanitizer leaf extract turmeric was made with a variation of the volume of the leaves extract of turmeric as much as $0 \mathrm{~mL}, 5 \mathrm{~mL}, 10 \mathrm{~mL}, 15 \mathrm{~mL}$, and $20 \mathrm{~mL}$, then tested by organoleptic test, viscosity test, $\mathrm{pH}$ test, and antibacterial test. On organoleptic testing in the form of color, scent, and texture to get highest the highest of successive leaves extract turmeric $10 \mathrm{~mL}, 10 \mathrm{~mL}, 5 \mathrm{~mL}$. As for the lowest value on the organoleptic test (color, scent, texture) in a row on the leaf extract turmeric $20 \mathrm{~mL}, 0 \mathrm{~mL}, 0 \mathrm{~mL}$. test the viscosity of the highest to be in formulation $1(0 \mathrm{~mL})$ and the lowest in formulation $5(20 \mathrm{~mL})$. Moreover, the $\mathrm{pH}$ test indicates the formulation of the highest be on formulation $1(0 \mathrm{~mL})$ and formulation 5 $(20 \mathrm{~mL})$, the lowest on formulation $3(10 \mathrm{~mL})$. as for antibacterial test, hand sanitizer leaf extract turmeric has the inhibition zone in S. Aureus bacteria compared E. Coli bacteria. The best formulation of turmeric leaf extract hand sanitizer based on all types of successive test is formulation $4(15 \mathrm{~mL})$, formulation $3(10 \mathrm{~mL})$, formulation $2(5 \mathrm{~mL})$, formulation $1(0 \mathrm{~mL})$, and the lowest quality of hand sanitizer of turmeric leaf extract is formulation $5(20 \mathrm{~mL})$.
\end{abstract}

\section{PENDAHULUAN}

Berbagai jenis bakteri menempel pada tangan kita setiap harinya melalui kontak fisik, yang dapat menyebabkan timbulnya berbagai penyakit salah satunya diare. Diare merupakan penyakit yang ditandai dengan feses berbentuk cair atau lembek dikarenakan chymus melewati usus secara cepat sehingga proses absorpsi tidak terjadi yang menyebabkan tubuh mengalami dehidrasi atau ketidakseimbangan elektrolit [1].
Penyakit diare merupakan penyakit yang dapat mengakibatkan kematian pada balita terutama di negara berkembang. Menurut WHO (World Health Organization), kasus diare tiap tahun diperkirakan mencapai 1,5 miliar kasus pada anak dengan angka kematian mencapai 525.000 pada anak dan balita tiap tahunnya [2].

Di negara Indonesia, diare masuk sebagai salah satu penyebab terganggunya kesehatan pada masyarakat. Berdasarkan survei yang dilakukan oleh Kementrian Kesehatan RI (2011), didapatkan 
hasil bahwa dari tahun 2000 hingga 2009 terlihat kecenderungan penyakit ini terus terjadi. Pada tahun 2000 penyakit diare terjadi sebanyak 4771.3 penduduk, tahun 2001 turun menjadi 2871.4 penduduk dan tahun 2002 sebanyak 1594.8 penduduk. Tahun 2003 dan tahun 2005, insiden cendrung naik yaitu berturu-turut sebanyak 12897 dan 20483 penduduk. Tahun 2005 sebanyak 2897 penduduk, tahun 2006 sebanyak 4263.5 penduduk, tahun 2007 sebanyak 5006.7 penduduk, tahun 2008 sebanyak 4839.6 penduduk dan tahun 2009 sebanyak 4393.9 penduduk [3]. Pada tahun 20142015 secara berturut jumlah penderita diare adalah sebanyak 1.164 kasus dan 1.030 kasus, sedangkan pada tahun 2016 turun menjadi sebanyak 862 kasus [4]. Penyakit diare ini disebabkan oleh bakteri Escherichia coli dan Staphylococcus aureus, yang menjadi masalah utama dalam kesehatan pencernaan.

Staphylococcus aureus adalah bakteri berbentuk patogen oportunistik yang tumbuh dan berkembang di permukaan kulit dan mukosa individu. Bakteri ini dapat menyebabkan berbagai penyakit pada manusia. Mulai dari penyakit yang disebabkan oleh toxin, seperti toxic shock syndrome, hingga penyakit-penyakit mematikan seperti endocarditis, septicemia, osteomyelitis, dan pneumonia [5]. Sedangkan Escherichia coli adalah bakteri gram negatif yang berbentuk basil dengan diameter 0,5 mikrometer dan banjang berkisar 2 mikrometer. Bakteri ini hidup di dalam saluran pencernaan manusia pada rentang suhu 20-40 ${ }^{\circ} \mathrm{C}$ dan optimum pada suhu $37^{\circ} \mathrm{C}$ [6].

Untuk menghambat perkembangan bakteri biasanya dilakukan dengan mencuci tangan dengan sabun. Dewasa ini telah banyak diciptakan pembersih tangan antiseptik atau disebut hand sanitizer yang dapat mempermudah terutama dalam keadaan tidak ada air. Hand sanitizer adalah salah satu bahan antiseptik berupa gel atau spray yang cukup populer digunakan masyarakat sebagai media pencuci tangan yang praktis. Penggunaan hand sanitizer memiliki kelebihan yaitu mampu membunuh bakteri secara cepat. Hal ini disebabkan karna hand sanitizer terbuat dari alkohol. Baik dalam bentuk etanol, propanol, ataupun isopropanol dengan rentang konsentrasi mulai dari $60 \%$ higga $80 \%$, triklosan dan juga golongan fenol yang berupa klorheksidin. Semua senyawa ini memiliki kemampuan merusak protein yang ada pada sel kuman kemudian mengkoagolasinya [7].

Daun kunyit merupakan tanaman yang biasanya dimanfaatkan sebagai bumbu beberapa masakan, sehingga pemanfaatan dari daun kunyit masih terbatas [8]. Daun kunyit mengandung senyawa metabolit sekunder seperti saponin, tannin, flavonoid, triterpenoid, dan steroid [9]. Selain itu, daun kunyit mengandung minyak atsiri golongan monoterpene, sesquiterpene, diterpene, aldehid, ester, eter, keton, serta pinen, limonen dan myrcene [10]. Kandungan metabolit sekunder tersebut mempunyai gugus polar dan nonpolar yang bersifat aktif. Kemampuan tiap senyawa ini dapat bersifat sebagai antibakteri seperti bakteri Staphylococcus aureus dan Escherichia coli. Akan tetapi, kemampuan daun kunyit yang dapat bersifat sebagai antibakteri belum banyak dikembangkan. Oleh karena itu, peneliti tertarik mengambil judul "Uji Kualitas Hand sanitizer Ekstrak Daun Kunyit (Curcuma longa Linn)".

\section{EKSPERIMEN}

Penelitian ini menggunakan pendekatan kuantitatif dengan melakukan eksperimen di laboratorium untuk pembuatan produk hand sanitizer. Produk hand sanitizer yang dilakukan kemudian ditambahkan dengan variasi volume pada ekstrak daun kunyit pada setiap formulasi. Adapun variasi volume ektrak daun kunyit yang di gunakan yaitu $0 \mathrm{~mL}, 5 \mathrm{~mL}, 10 \mathrm{~mL}, 15 \mathrm{~mL}$, dan 20 $\mathrm{mL}$.

\section{Material}

Ekstrak rebusan daun kunyit, Escherichia coli, Staphylococcus Aureus, larutan buffer (Merck), LABS (Linier Alkil Benzen Sulfonat), Hec (Hydroxyethyl Cellulose), larutan $\mathrm{NaOH} 1 \mathrm{M}$ (Merck), alkohol (Merck), gliserin (Merck), air.

\section{Instrumentasi}

Viskometer oswald (pyrex), botol, piknometer (pyrex), batang pengaduk (pyrex), gelas kimia (pyrex), gelas ukur (pyrex), timbangan (Fujitsu), cawan petri (pyrex), inkubator (memmert IN30), kertas cakram (Paper Disc) (OXOID), media NA (OXOID CM0003), hotplate (Thermo scientific), pipet volum (pyrex), kertas saring.

\section{Prosedur}

\section{Pembuatan hand sanitizer}

Dimasukkan $50 \mathrm{~mL}$ akohol $70 \%$ ke dalam gelas kimia $500 \mathrm{ml}$. Ditambahkan $1 \mathrm{~g} \mathrm{Hec}$ (Hydroxyethyl Cellulose) ke dalam gelas kimia yang berisi alkohol kemudian diaduk hingga campuran homogen. Ditambahkan 5 tetes larutan $\mathrm{NaOH}$ (Sodium Hidroksida) kemudian diaduk sampai sedikit mengental. Ditambakan 2 
$\mathrm{mL}$ gliserin kemudian diaduk hingga rata. Ditambahkan $3 \mathrm{ml}$ LABS (Linier Alkil Benzen Sulfonat), kemudian diaduk sampai tercampur rata. Ditambahkan air $30 \mathrm{ml}$ kemudian diaduk hingga campuran homogen dan sedikit mengental.

\section{Pembuatan ekstrak daun kunyit}

Daun kunyit dengan ciri-ciri berwarna hijau, tidak terlalu muda dan tua, bebas dari penyakit, diambil dri daerah Dusun Dangah, Desa Jelantik, Kec. Jonggat, Kab. Lombok Tengah, Provinsi Nusa Tenggara Barat. Sampel dicuci menggunakan air bersih yang mengalir, kemudian dipotong kecil-kecil dengan ukuran $\pm 2 \mathrm{~cm}$. Selanjutnya ditimbang beratnya dan ditambahkan air dengan perbandingan 1:1 (100 gram daun kunyit : $100 \mathrm{~mL}$ air). Kemudian dimaserasi panas dengan cara direbus selama 20 menit pada suhu $40-50{ }^{\circ} \mathrm{C}$. Disaring air ekstrak daun kunyit.

\section{Pembuatan hand sanitizer ekstrak daun kunyit}

Produk Hand sanitizer dibagi menjadi 5 formulasi $(\mathrm{F})$ dan dicampur dengan ekstrak daun kunyit dan dilakukan dengan 4 kali pengulangan. Pada tiap formulasi memiliki variasi volume pada ekstrak daun kunyit dapat ditunjukkan pada Tabel 1.

Tabel 1. Pembuatan hand sanitizer ekstrak daun kunyit

\begin{tabular}{ccc}
\hline Perlakuan & Hand sanitizer & $\begin{array}{c}\text { Ekstrak } \\
\text { daun kunyit }\end{array}$ \\
\hline F1 & $100 \mathrm{~mL}$ Hand sanitizer & $0 \mathrm{~mL}$ \\
F2 & $100 \mathrm{~mL}$ Hand sanitizer & $5 \mathrm{~mL}$ \\
F3 & $100 \mathrm{~mL}$ Hand sanitizer & $10 \mathrm{~mL}$ \\
F4 & $100 \mathrm{~mL}$ Hand sanitizer & $15 \mathrm{~mL}$ \\
F5 & $100 \mathrm{~mL}$ Hand sanitizer & $20 \mathrm{~mL}$ \\
\hline
\end{tabular}

\section{Uji organoleptik}

Uji organoleptik meliputi warna, aroma dan tekstur terhadap 5 formulasi di uji pada panelis yang tidak terlatih sebanyak 25 orang. Setiap panelis akan memberikan nilai sesuai dengan tingkat kesukaannya. Adapun cara penilaiannya adalah 5: sangat suka, 4: suka. 3: biasa, 2: tidak suka, dan 1: sangat tidak suka [11].

\section{Uji $p H$}

Uji pH pada tiap formulasi dilakukan menggunakan $\mathrm{pH}$ meter dengan cara menyiapkan alat $\mathrm{pH}$ meter digital kemudian dikalibrasi dengan larutan buffer yang telah dibuat. Selanjutnya dibersihkan elektroda dan dimasukkan ke dalam sampel. Dibaca dan dicatat $\mathrm{pH}$ yang pada skala $\mathrm{pH}$ meter [12].

\section{Uji viskositas}

Uji viskositas merupakan uji untuk mengukur tingkat kekentalan suatu produk. Standar viskositas dapat dikatakan memiliki viskositas yang baik apabila berada pada range 2000-4000 cPs. Adapun penelitian ini menggunakan viskometer oswald.

Rumus yang digunakan untuk menentukan kekentalan berdasarkan viskometer oswald sebagai berikut [13]:

$$
\eta_{1}=\frac{\eta_{2} \cdot \rho_{1} \cdot t_{1}}{\rho_{2} \cdot t_{2}}
$$

Dimana :

$\eta_{1}=$ Koefisien viskositas fluida

$\eta_{2}=$ Koefisien viskositas air

$t_{1}=$ Waktu yang dibutuhkan fluida jatuh

$t_{2}=$ Waktu yang dibutuhkan air jatuh

$\rho_{1}=$ Massa jenis fluida

$\rho_{2}=$ Massa jenis air

\section{Uji antibakteri}

Uji aktivitas antibakteri sediaan handsanitizer ekstrak daun kunyit dilakukan menggunakan metode difusi agar dengan kertas cakram (Paper disc) berdiameter $6 \mathrm{~mm}$ terhadap bakteri $S$. aureus dan E. coli. Uji ini dilakukan sebanyak 3 kali pengulangan. Adapun langkahlangkah pengujian sebagai berikut [14]:

1) Dimasukkan Paper disc ke dalam setiap sampel yang berisi Hand sanitizer + ekstrak daun kunyit dengan variasi volume $0 \mathrm{~mL}, 5$ $\mathrm{mL}, 10 \mathrm{~mL}, 15 \mathrm{~mL}, 20 \mathrm{~mL}$.

2) Diletakkan di atas media NA yang telah diinkubasi dengan bakteri.

3) Dilakukan inkubasi pada suhu $37{ }^{\circ} \mathrm{C}$ selama $1 \times 24$ jam.

4) Dilakukan pengamatan terhadap terbentuknya zona hambat disekitar Paper disc.

\section{HASIL DAN PEMBAHASAN}

\section{Uji organoleptik}

Uji organoleptik di uji berdasarkan 3 katagori (warna, aroma, dan tekstur) menggunakan 25 panelis. Berdasarkan hasil penilaian yang telah diberikan oleh penelis menunjukkan bahwa kualitas hand sanitizer ekstrak daun kunyit termasuk ke dalam katagori 
suka. Adapun hasil yang diperoleh pada tiap formulasi dapat dilihat pada Tabel 2 hasil percobaan berikut ini.

Tabel 2. Nilai rata-rata uji organopletik (warna, aroma, tekstur) terhadap kualitas hand sanitizer ekstrak daun kunyit

\begin{tabular}{cccc}
\hline Perlakuan & Warna & Aroma & Tekstur \\
\hline F1 $(\mathbf{0} \mathbf{~ m L})$ & $3.80^{* \mathrm{a}}$ & $3.60^{* \mathrm{a}}$ & 4.20 \\
F2 $(\mathbf{5} \mathbf{~ m L})$ & $4.10^{* \mathrm{~b}}$ & $4.15^{* \mathrm{~b}}$ & 4.40 \\
F3 $(\mathbf{1 0} \mathbf{~ m L})$ & $4.45^{* \mathrm{c}}$ & $4.30^{* \mathrm{~b}}$ & 4.15 \\
F4 $(\mathbf{1 5} \mathbf{~ m L})$ & $4.30^{* \mathrm{c}}$ & $4.10^{* \mathrm{~b}}$ & 4.40 \\
F5 $(\mathbf{2 0} \mathbf{~ m L})$ & $3.65^{* \mathrm{a}}$ & $3.75^{* \mathrm{a}}$ & 4.30
\end{tabular}

*a-c superscript huruf yang berbeda pada kolom yang sama menunjukkan perbedaan nyata $(\mathrm{P}<0.05)$ dengan uji lanjut BNT.

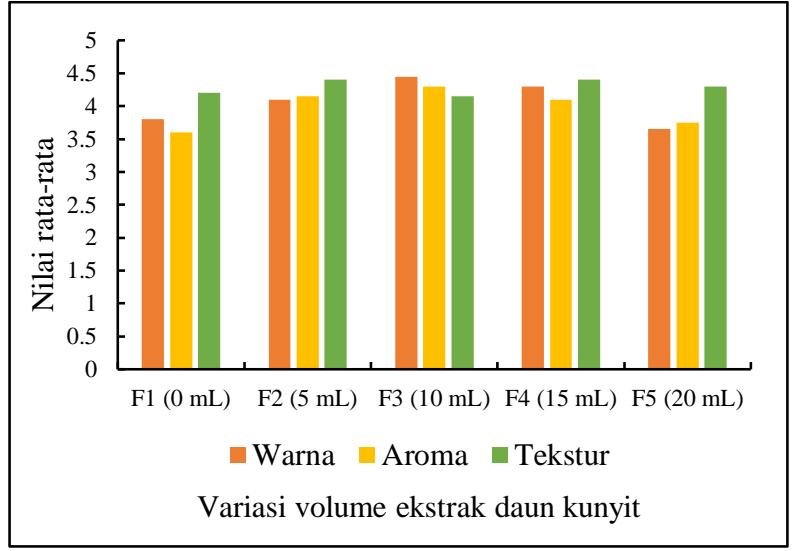

Gambar 1. Skor penilaian panelis terhadap warna, aroma, dan tekstur Hand Sanitizer ekstrak daun kunyit.

Berdasarkan hasil pengujian organoleptik pada Gambar 1, produk hand sanitizer ekstrak daun kunyit menunjukkan hasil bahwa pada uji tekstur tidak terdapat perbedaan pengaruh yang signifikan. Adapun pada pengujian warna dan aroma, hasil paling tinggi berada pada formulasi 3 dengan jumlah ekstrak daun kunyit sebanyak 10 $\mathrm{mL}$. dan hasil terendah berada pada formulasi 5 dengan jumlah ekstrak daun kunyit sebanyak 20 $\mathrm{mL}$. Adapun pada pengujian tekstur menunjukkan hasil tertinggi berada pada formulasi 2 dan 4 dengan jumah ekstrak daun kunyit sebanyak $5 \mathrm{~mL}$ dan $15 \mathrm{~mL}$. Sedangkan nilai terendah berada pada formulasi 1 dengan jumlah ekstrak daun kunyit sebanyak $0 \mathrm{~mL}$. Penggunaan ekstrak daun kunyit dapat memberikan pewarna alami pada produk hand sanitizer dikarenakan daun kunyit dapat memiliki kandungan pigmen warna seperti klorofil, antosianin, karatenoid, kurkumin. betalains dan lainnya. Selain itu, senyawa metabolit sekunder yang dimiliki daun kunyit seperti flavonoid dan tanin juga dapat berfungsi sebagai pewarna alami [15]. Aroma atau wangi, biasanya dihasilkan dari senyawa-senyawa volatil yang timbul secara alami maupun melalui proses pengolahan seperti perebusan, pemanggangan mapun proses lainnya. Perubahan yang terjadi pada aroma biasanya terjadi karena penguapan senyawa-senyawa volatil, dekomposisi protein dan lemak, serta karamelisasi karbohidrat yang disebabkan karena proses pemanasan. Senyawa volatil yang dapat menghasilkan aroma dari tanaman dapat berupa senyawa keton, alkohol, hidrokarbon jenuh serta aldehid [16].

\section{Uji pH}

Uji $\mathrm{pH}$ yang dilakukan menunjukkan bahwa hand sanitizer ekstrak daun kunyit berada pada $\mathrm{pH}$ hand sanitizer umumnya yang memenuhi persyaratan SNI No. 06-2588 berkisar antara 4.56.5 [17]. Karena apabila produk hand sanitizer berada pada $\mathrm{pH}$ Asam maka akan menyebabkan iritasi pada kulit. Sedangkan apabila hand sanitizer berada pada $\mathrm{pH}$ basa maka akan menyebabkan pengelupasan pada tangan [18]. Adapun nilai $\mathrm{pH}$ yang didapat pada uji ini ditunjukkan pada Gambar 2.

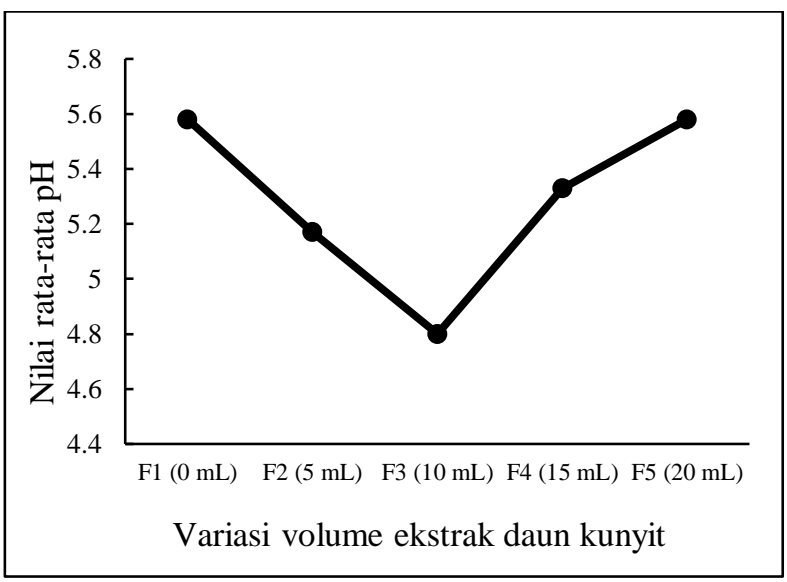

Gambar 2. Uji pH hand sanitizer ekstrak daun kunyit

Gambar 2 menunjukkan bahwa variasi volume pada hand sanitzer ekstrak daun kunyit berdasarkan uji statistik yang dilakukan menunjukkan bahwa variasi volume pada ekstrak daun kunyit tidak memiliki pengaruh yang signifikan. Hal ini karena kandungan senyawa metabolit sekunder pada ekstrak daun kunyit adalah sama, seperti senyawa tanin, saponin, alkaloid, maupun flavonoid sehingga jumlah variasi volume ekstrak daun kunyit tidak terlalu mempengaruhi $\mathrm{pH}$ pada tiap formulasi. Adapun bahan pada formulasi hand sanitizer yang juga dapat berfungsi sebagai penyeimbang $\mathrm{pH}$ adalah gliserin. Gliserin dapat membuat formulasi menjadi jernih dan transparan. Selain itu, gliserin juga dapat meningkatkan daya sebar serta menjaga kelembaban kulit [19]. 


\section{Uji viskositas}

Uji viskositas hand sanitizer ekstrak daun kunyit dilakukan menggunakan alat viskometer oswald dari 5 sampel perlakuan. Adapun hasil yang didapatkan pada uji viskositas disajikan pada Tabel 3 dibawah ini.

Tabel 3. Hasil uji viskositas hand sanitizer ekstrak daun kunyit

\begin{tabular}{cccc}
\hline Perlakuan & $\begin{array}{c}\text { Hasil } \\
\text { viskosita } \\
\text { S (cps) }\end{array}$ & $\begin{array}{c}\text { Standar } \\
\text { viskositas } \\
\text { (cps) }\end{array}$ & $\begin{array}{c}\text { Nilai } \\
\text { rerata+ } \\
\text { BNT }\end{array}$ \\
\hline F1 $(0 \mathrm{~mL})$ & $2.509,97$ & $2000-4000$ & $2.841,19^{*_{\mathrm{c}}}$ \\
$\mathrm{F} 2(5 \mathrm{~mL})$ & $2.351,08$ & $2000-4000$ & $2.682,30^{* \mathrm{~b}}$ \\
$\mathrm{~F} 3(10 \mathrm{~mL})$ & $2.166,68$ & $2000-4000$ & $2.497,90^{* \mathrm{a}}$ \\
$\mathrm{F} 4(15 \mathrm{~mL})$ & $2.111,95$ & $2000-4000$ & $2.443,17^{*_{\mathrm{a}}}$ \\
$\mathrm{F} 5(20 \mathrm{~mL})$ & $1.916,70$ & $2000-4000$ & $2.247,92^{*_{\mathrm{a}}}$ \\
\hline *a-c superscript huruf yang berbeda pada kolom yang \\
sama menunjukkan perbedaan nyata (P< 0.05$)$ dengan \\
uji lanjut BNT.
\end{tabular}

Tabel 3 di atas menunjukkan bahwa hand sanitizer ekstrak daun kunyit berada pada viskositas sediaan hand sanitizer secara umum yaitu berkisar antara 2000-4000 cPs [20]. Nilai kekentalan dari formulasi 1 sampai 5 tidak jauh beda. Hal ini, disebabkan karena jumlah bahan utama dalam pembutan hand sanitizer ini sama. Akan tetapi, terjadi perubahan kekentalan ini disebabkan karena ekstrak daun kunyit yang digunakan berbentuk cair. Sehingga semakin banyak jumlah ekstrak daun kunyit maka semakin menurun nilai kekentalannya.

\section{Uji antibakteri}

Uji antibakteri terhadap kualitas hand sanitizer ekstrak daun kunyit dengan 5 formulasi di uji menggunakan bakteri $E$. coli dan $S$. aures. Berdasarkan hasil yang didapatkan pada penelitian ini, menunjukkan bahwa hand sanitizer ekstrak daun kunyit dapat berpotensi sebagai antibakteri. Adapun hasil penelitian hand sanitizer ekstrak daun kunyit tehadap zona hambat bakteri E. coli dan $S$. aures dapat dilihat pada Tabel 4, Gambar 3, dan Gambar 4 dibawah ini.

Tabel 4. Nilai rata-rata uji zona hambat bakteri E.Coli dan S. Aureus.

\begin{tabular}{cccc}
\hline Perlakuan & $\begin{array}{c}\text { Zona } \\
\text { Hambat } \\
\text { E. } \text { Coli }\end{array}$ & $\begin{array}{c}\text { Nilai } \\
\text { rerata+BNT } \\
\text { E. } \text { Coli }\end{array}$ & $\begin{array}{c}\text { Zona } \\
\text { Hambat } \\
\text { S. } \text { Aureus }\end{array}$ \\
\hline F1 $(0 \mathrm{~mL})$ & $12.12 \mathrm{~mm}$ & $13.98^{*_{b}}$ & $9.75 \mathrm{~mm}$ \\
F2 $(5 \mathrm{~mL})$ & $13.13 \mathrm{~mm}$ & $15.23^{*_{b}}$ & $7.62 \mathrm{~mm}$ \\
F3 $(10 \mathrm{~mL})$ & $8.37 \mathrm{~mm}$ & $10.23^{*_{a}}$ & $9.25 \mathrm{~mm}$ \\
F4 $(15 \mathrm{~mL})$ & $9.50 \mathrm{~mm}$ & $11.36^{*_{a}}$ & $14.37 \mathrm{~mm}$ \\
F5 $(20 \mathrm{~mL})$ & $9.62 \mathrm{~mm}$ & $11.48^{*_{\mathrm{a}}}$ & $9.37 \mathrm{~mm}$ \\
\hline
\end{tabular}

*a-b superscript huruf yang berbeda pada kolom yang sama menunjukkan perbedaan nyata $(\mathrm{P}<0.05)$ dengan uji lanjut BNT.
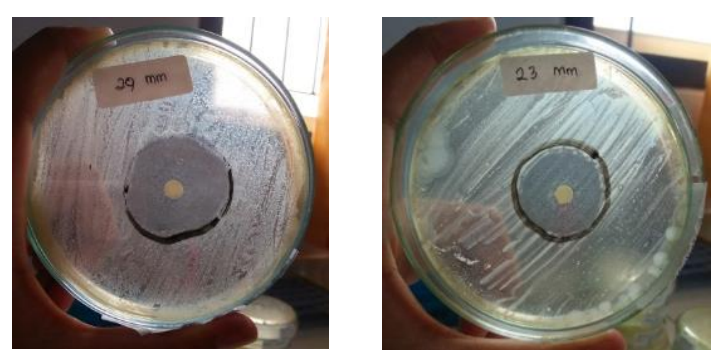

Gambar 3. Zona hambat bakteri pada Escherichia coli
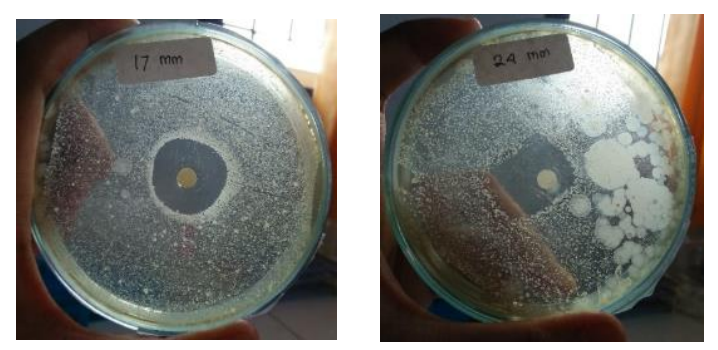

Gambar 4. zona hambat bakteri pada Staphylococcus aureus

Tabel 4 menunjukkan hasil bahwa ke-5 formulasi dari Hand sanitizer dengan penambahan ekstrak daun kunyit pada bakteri E. Coli dengan zona hambat paling tinggi yaitu pada F2 $(5 \mathrm{~mL})$ memiliki zona hambat bakteri yang paling besar dan terendah pada F3 (10 mL). Adapun pada pengujian dengan bakteri $S$. Aureus menunjukkan hasil bahwa ke-5 formulasi tidak memiliki pengaruh yang signifikan. Sedangkan untuk nilai zona hambat menunjukkan bahwa F4 (15 mL) berada pada zona hambat yang paling tinggi dan terendah pada F2 $(5 \mathrm{~mL})$. Sedangkan pada pengujian zona hambat bakteri berdasarkan kedua jenis bakteri meunjukkan bahwa kualitas Hand sanitizer ekstrak daun kunyit memiliki zona hambat lebih besar pada bakteri gram positif ( $S$. Aureus) dibanding bakteri gram negatif (E. Coli). Hal ini dikarenakan struktur dinding sel pada bakteri gram positif lebih kompleks dibanding bakteri gram negatif. dinding sel yang mudah mengalami denaturasi adalah dinding sel yang tersusun dari polisakarida dibanding dinding sel yang tersusun dari fospolipid. Pada bakteri gram posistif (E. Coli), dinding selnya tersusun dari peptidoglikan, asam terikoat dan asam terikuronat. Sedangkan bakteri gram negatif (S. Aureus) memiliki peptidoglikan yang sangat sedikit dan berada diantara selaput luar dan selaput dalam dinding sel [21]. Akibat dari sedikitnya kandungan peptidoglikan dari bakteri gram negatif ini, menjadikan senyawa metabolit sekunder yang terdapat pada daun kunyit lebih mudah mengalami proses denaturasi sel dibanding bakteri gram 
positif. Senyawa yang berpotensi sebagai antibakteri pada ekstrak daun kunyit berupa senyawa metabolit sekunder seperti saponin, tannin, terpenoid, triterpenoid, dan flavonoid yang bersifat polar dan polar sehingga dapat menghambat pertumbuhan bakteri dengan cara mendenaturasi protein pada sel bakteri [22].

\section{SIMPULAN}

Berdasarkan hasil yang telah dipaparkan, dapat disimpulkan bahwa; Hasil uji kualitas hand sanitizer ekstrak daun kunyit dengan berbagai variasi volume memiliki kualitas yang baik sesuai Standar Nasional Indonesia (SNI). Hasil uji secara kuantitatif menunjukkan nilai yang didapatkan pada uji pH yaitu pada 4,5-6,0. Pada uji viskositas dengan nilai 2000-4000 cPs dan uji antibakteri menunjukkan zona hambat yang kuat terhadap bakteri Escherichia coli dan Staphylococcus aureus. Formulasi terbaik pada kualitas hand sanitizer ekstrak daun kunyit berdasarkan semua jenis uji berturut-turut adalah formulasi $4(15 \mathrm{~mL})$, formulasi $3(10 \mathrm{~mL})$, formulasi $2(5 \mathrm{~mL})$, formulasi $1(0 \mathrm{~mL})$ dan kualitas terendah hand sanitizer ekstrak daun kunyit adalah formulasi 5 (20 mL).

\section{UCAPAN TERIMA KASIH}

Penulis ucapkan terimakasih kepada labororatorium UIN Mataram yang telah menyediakan alat dan bahan dalam pembuatan produk dan laboratorium Politeknik Medika Farma Husana Mataram dalam pengujian antibakteri. hasil analisis, dan lain-lain.

\section{REFERENSI}

[1] K. Tarman, S. Purwaningsih, and A.A.P.A.P. Negara, "Aktivitas Antibakteri Ekstrak Daun Bakau Hitam (Rhizophora Mucronata) terhadap Bakteri Penyebab Diare", Jurnal Pengolahan Hasil Perikanan Indonesia, vol. 16, no. 3, pp. 249-258, 2014.

[2] Z. Bakri, M. Hatta, and M.N. Massi, "Deteksi Keberadaan Bakteri Escherichia Coli O157:H7 pada Feses Penderita Diare dengan Metode Kultur dan PCR", JST kesehatan, vol. 5, no. 2, pp. 184-192, 2015.

[3] K.K. RI, Situasi Diare di Indonesia, Jakarta: Subdit Pengendalian dan Infeksi Pencernaan Kemenkes RI, 2011.

[4] B. Afriani, "Peranan Petugas Kesehatan dan
Ketersediaan Sarana Air Bersih dengan Kejadian Diare", Ilmu Kesehatan, vol. 2, pp. 118-119, 2017.

[5] Mardiah, "Uji Resistensi Staphylococcus Aureus terhadap Antibiotik, Tmoxillin, Tetracyclin dan Propolis", Ilmu Alam dan Lingkungan, vol. 8, no. 16, pp. 1-6, 2017.

[6] S. Fhitryani, D. Suryanto, and A. Karim, "Pemeriksaan Escherichia Coli, Staphylococcus Aureus dan Salmonela Sp. pada Jamu Gendong yang Dijajakan di Kota Medan", Biologi Lingkungan, Industri, Kesehatan, vol. 3, no. 2, pp. 142-151, 2017.

[7] A. Asngad, A.B.R., and Nopitasari, "Kualitas Gel Pembersih Tangan (Handsanitizer) dari Ekstrak Batang Pisang dengan Penambahan Alkohol, Triklosan dan Gliserin yang Berbeda Dosisnya", Bioeksperimen, vol. 4, no. 2, pp. 61-70, 2018.

[8] E. Septiana and P. Simanjuntak, "Aktivitas Antimikroba dan Antioksidan Ekstrak Beberapa Bagian Tanaman Kunyit (Curcuma longan)", Fitofarmaka, vol. 5, no. 1, pp. 3140, 2015.

[9] A.S.S. Pulungan, "Aktivitas Antijamur Ekstrak Etanol Daun Kunyit (Curcuma Longa Linn) terhadap Jamur Candida Albican", Biologi Lingkungan, Industri, Kesehatan, vol. 3, no. 2, pp. 120-124, 2017.

[10] Aseptianova. "Pengaruh Ekstrak Daun Kunyit (Curcuma Longa Linn) sebagai Insektisida Elektrik terhadap Mortalitas Nyamuk Culex Sp. L", Pro-life, vol. 6, no. 1, pp. 44-54, 2019.

[11] A.Z. Robbia, "Perbandingan Pengaruh Ekstrak Lidah Buaya (Aloe vera) dan Ekstrak Daun Sirih (Piper betle linn) terhadap Kualitas Produk Hand Soap", Universitas Islam Negeri Mataram, Mataram, 2019.

[12] D. Lamusu, "Uji Organoleptik Jalangkonte Ubi Jalar Ungu (Ipomoea batatas L) Sebagai Upaya Diversifikasi Pangan", Pengolahan Pangan, vol. 3, no. 1, pp. 9-15, 2018.

[13] D. Apriani, Gusnedi, and Y. Darvina, "Studi Tentang Nilai Viskositas Madu Hutan dari Beberapa Daerah di Sumatera Barat untuk Mengetahui Kualitas Madu", Pillar of Phisics, vol. 2, pp. 91-98, 2013.

[14] M. Maryadi, F. Yusuf, and S. Farida, "Uji Aktivitas Antibakteri Ekstrak Etanol Tanaman Obat Suku Musi di Kabupaten Musi Banyuasin, Sumatera Selatan", Kefarmasian Indonesia, vol. 7, no. 2, pp. 127-135, 2017. 
[15] T. Pujilestari, "Sumber dan Pemanfaatan Zat Warna Alam untuk Keperluan Industri", Dinamika Kerajinan dan Batik, vol. 32, no. 2, pp. 93-106, 2015.

[16] R. Saragih, "Uji Kesukaan Panelis pada Teh Daun Torbangun (Coleus Amboinicus)", Widya Kesehatan dan Lingkungan, vol. 1, no. 1, pp. 46-52, 2014.

[17] M.A. Putri, M.E. Saputra, I.N. Amanah, and V.A. Fabiani, "Uji Sifat Fisik Sediaan Gel Hand Sanitizer Ekstrak Daun Pucuk Idat (Cratoxylum Glaucum)", dalam Universitas Bangka Belitung, Bangka Belitung, 2019.

[18] S. Titaley, F. and W.A. Lolo, "Formulasi dan Uji Efektifitas Sediaan Gel Ekstra Etanol Daun Mangrove Api-Api (Avicennia Marina) Sebagai Antiseptik Tangan", Ilmiah Farmasi, vol. 3, no. 2, pp. 99-106, 2014.
[19] J.I. Wijaya, "Formulasi Sediaan Gel Hand Sanitizer dengan Bahan Aktif Triklosan 1,5\% dan 2\%", Ilmiah Mahasiswa Universitas Surabaya, vol. 2, no. 1, pp. 1-14, 2013.

[20] R.H. Stevani and D. Ratnasari, "Formulasi Sediaan Hand Sanitizer dari Ekstrak Biji Pangi (Pangium Edule Reinw)", Media Farmasi, vol. 15, no. 2, pp. 197-204, 2019.

[21] E.P. Rini and E.R. Nugraheni, "Uji Daya Hambat Berbagai Merek Hand Sanitizer Gel terhadap Pertumbuhan Bakteri Escherichia Coli dan Staphylococcus Aureus", journal of pharmaceutical science and clinical research, vol. 1, pp. 18-26, 2018.

[22] I. Lexmana, Aktivitas Antimikroba Ekstrak Daun Kunyit (Curcuma Domestica Val.) terhadap Eschericiha Coli, Shigella Dysentriase dan Lactobacillus Acidophylus, Medan: Universitas Sumatera Utara, 2014. 